\title{
Effect of intercropping system and sowing dates of Maize on population of some insect pests and Coccinella spp. predators
}

\author{
Abd-El -Atty, S. F.; Hegab, M. E. M. and S. Z. S. Shetaia \\ Plant Protection Research Institute, ARC, Dokki, Giza
}

\begin{abstract}
The present work was carried out during 2011 and 2012 seasons, at Menia El-Kamh district, Sharkia Governorate, Egypt to study the effect of the intercropping system and sowing date on the population density of some insect pests and predators associated with Maize and Soybean plants.

The insect pests surveyed on Maize plants were aphids, Sesamia cretica, Ostrinia nubilalis and Chilo agamemnon. The results indicated that the intercropping system culture showed considerable decrease in numbers of insect pests and also, coccinellid predators. While, the highest population density of the pest insects and coccinellid predators were recorded on solid culture during 2011 and 2012 seasons, respectively.

The insect pests and coccinellid predators recorded on Soybean plants were Aphis gossypii, Spodoptera littoralis \& Thrips tabaci and Coccinella spp. Also, intercropping Maize with Soybean caused lower population density, relatively, of insect pests and coccinellid predators on Soybean plants than on Soybean growing in solid system during the two seasons 2011 and 2012, respectively.

The planting date had effective role on the level of the population density of both insect pests and predators on Maize and Soybean plants. Whereas the third sowing date caused highest population density, relatively of both insect pests and coccinellid predators on Maize and Soybean plants except for Sesamia cretica which recorded highest number at first planting date. Also, the highest numbers of insect predators Coccinella spp. on soybean plants were recorded in the $1^{\text {st }}$ week of July during 2011 and 2012 seasons, respectively.
\end{abstract}

Key words: Intercropping Maize with Soybean, insect pests, Coccinella spp.

\section{Introduction}

The first successful soybean production in 1937 was in Nigeria located in the southern guinea savannah agro-ecological zone of the country with the Malayan cultivar which was suitable for commercial production (Egbe, 1995). In Africa, Soybean is one of the leguminous crops selected for active research, production and utilization. It has potential of fixing atmospheric nitrogen $(\mathrm{N})$ besides meeting its own $\mathrm{N}$ requirement and serves as a viable and low cost medium for soil fertility improvement. An important component crop in Soybean system is Maize. Soybean has the potential for improving human diet through supplying high quality protein as well as animal feed and serves as a source of raw material base for agro-industries (Atungwu and Afolabi, 2001). Maize (Zea mays L.), which is one of the most important cereal crops grown in Africa and ranks as the third most cultivated crop in Nigeria (Ayeni, 1987), features prominently in inter-cropping systems involving legume and non-legume crops such as Soybean , Cowpea, Cassava, Yam, etc. Maize is used for human food, livestock feed and as a source of industrial raw material for the production of oil, alcohol and starch. Grain legume/cereal crop mixtures are very popular among small scale farmers in West Africa. The traditional farmers have adopted mixed cropping for various reasons which include increased monetary returns, insurance against crop failure and reduction of pests and diseases (Muoneke and Asiegbu, 1997).

The present study aims to focus on the effect of certain agricultural practices such as intercropping system and sowing dates on the population density of some insect pests and predators associated with Maize and Soybean plants.

\section{Materials and Methods}

The present experiments carried out at Minia ELKamh, Sharkia Governorate, to achieve the effect of sowing dates on some insect pests and predators associated with Maize and Soybean crops under solid and intercropping system.

\section{The experimental design:}

The experimental design was split-split during two seasons. Treatment plots and sub plots consisted of 10 ridges ( 6 meters length and $70 \mathrm{~cm}$ width), each treatment with three replicates. Each plot was (10 ridges). In case of solid cultivation, one side of the ridge was planted with Maize at $30 \mathrm{~cm}$ space, while the another two sides of ridges were planted with Soybean at $20 \mathrm{~cm}$ spaces. In intercropping Maize of pioneer Karnk variety and Soybean Clark variety were planted 2 rows Maize and two rows Soybean, respectively. Samples (10 leaves/ sample) from each Soybean and Maize plants were taken randomly at weekly intervals. 
Effect of sowing date on the population density of insect pests and its coccinellid predators:

The sowing dates were selected on the $3^{\text {rd }}$ week of May, $2^{\text {nd }}$ week of June and $1^{\text {st }}$ week of July for both crops (Maize and Soybean) during the two seasons of 2011 and 2012, respectively.

Statistical analysis:

The obtained data were statistically analyzed according to proper F. value as described by Fisher (1950).

\section{Results and discussion}

I-Effect of intercropping system on population of: I-1-Insect pests attacking Maize plants: a-aphids:

Data in the Table (1) indicate that intercropping Maize with Soybean affected the corn-aphid infestation according to the presented data, whereas high infestation was recorded on solid Maize during the two seasons 2011 and 2012, respectively. While, with intercropping plantation, data showed decrease in aphid's numbers infested Maize plants during the same seasons of study. The mean numbers of aphids were 575.13 \& 479.59 and 443.63 \& 346.90 in solid and intercropping system for the two seasons for Maize plants, respectively. While, the mean numbers of aphids were 17.42, 12.70 and 13.60, 11.96 in solid and intercropping system during 2011 and 2012 seasons, respectively for Soybean plants.

\section{b- Sesamia critica:}

Data in Table (1) indicate that intercropping Maize with Soybean affected on $\boldsymbol{S}$. cretica infestation. Maize plants harbored high number of pest on solid Maize than with intercropping maize with Soybean during 2011 and 2012 seasons, respectively.

Table 1. Effect of planting system on the population density of some insect pests and coccinellid predators on Maize plants at Minia El-Kamh, Sharkia Governorate during 2011 and 2012 seasons.

\begin{tabular}{|c|c|c|c|c|c|c|c|c|c|c|}
\hline \multirow{3}{*}{ Planting system } & \multicolumn{10}{|c|}{ Mean number of insect /sample } \\
\hline & \multicolumn{2}{|c|}{ Aphids } & \multicolumn{2}{|c|}{$\begin{array}{l}\text { Sesamia } \\
\text { critica }\end{array}$} & \multicolumn{2}{|c|}{$\begin{array}{l}\text { Ostrinia } \\
\text { nubilalis }\end{array}$} & \multicolumn{2}{|c|}{$\begin{array}{c}\text { Chilo } \\
\text { agamemnon }\end{array}$} & \multicolumn{2}{|c|}{$\begin{array}{l}\text { Coccinella } \\
\text { spp. }\end{array}$} \\
\hline & 2011 & 2012 & 2011 & 2012 & 2011 & 2012 & 2011 & 2012 & 2011 & 2012 \\
\hline Solid & $575.13 a$ & $433.63 a$ & 7.46 & 6.07 & 9.93 & $10.95 a$ & 8.23 & 8.04 & 10.89 & 9.29 \\
\hline Intercropping & $479.59 b$ & $346.92 b$ & 5.32 & 5.19 & 8.76 & $9.76 b$ & 7.40 & 7.49 & 9.50 & 8.44 \\
\hline F. test & $* *$ & $* *$ & NS & NS & NS & $* *$ & NS & NS & NS & NS \\
\hline L.S.D. $0.05 \%$ & 22.67 & 16.24 & 6.80 & 4.53 & 4.53 & 160.33 & 4.53 & 5.78 & 5.78 & 5.77 \\
\hline
\end{tabular}

The mean numbers of $\boldsymbol{S}$. critica were 7.46 and 6.07 larvae in solid plantation; 5.32 and 5.19 in intercropping system for Maize plants for the two seasons, respectively.

\section{c-Ostrinia nubilalis:}

The obtained data in Table (1) indicate that high infestation with $\boldsymbol{O}$. nubilalis was recorded on solid Maize plantation during the two seasons. While, intercropping system showed considerable decrease of infested Maize plants during 2011 and 20102 seasons. The mean numbers of $\boldsymbol{O}$. nubilalis were $9.93 \& 10.95$ in solid and 8.67 \& 9.76 in intercropping during 2011 and 2012 seasons, respectively.

\section{d-Chilo agamemnon:}

Data presented in Table (1) show that Maize plants in solid plantation harbored higher number of C. agamemnon than in intercropping system. The mean numbers of $\boldsymbol{C}$. agamemnon were (8.23 \& 8.04) in solid and (7.40 \& 7.49) in intercropping system for the two seasons, respectively.

\section{I-2- Insect predators (Coccinella spp.)}

Data in Table (1) indicate that intercropping Maize with Soybean caused decrease in population density of Coccinella spp. While, Maize growing in solid system caused increase of Coccinella spp. population during 2011 and 2012 seasons, respectively. In this respect, El-Hariry, (1979); Youssef (1990); Mohamed et al. (1992); Abd-ElSalam and Shahinaz (1993) and Semeada et al. (1993) mentioned that intercropping Maize with Soybean caused lower population density of insect pests than on Maize growing in solid system.

\section{Soybean plants}

\section{1-1-Insect pests:}

Data in Table (2) indicate that intercropping Maize with Soybean affected insect pest's infestation.

\section{a-Aphis gossypii:}

Intercropping system showed a decrease of insect pest's infestation to Soybean plants during the two seasons of study. The mean numbers of aphids were (17.42 \& 13.60) on Soybean plants in solid system and (12.70 \&11.96) in intercropping system during 2011 and 2012 seasons, respectively.

\section{b-Spodoptera littoralis:}

The present results in Table (2) indicate that $S$. littoralis infestation to Soybean on solid system 
during 2011 and 2012 seasons was higher than in intercropping system. The pest insect numbers recorded 16.52 and 18.00 in 2011 season. While in season 2012, it was 13.73 \&13.02 insects for solid and intercropping systems, respectively.

Table 2. Effect of planting system on the population density of some insect pests and coccinellid predators on Soybean plants at Minia El-Kamh, Sharkia Governorate during 2011 and 2012 seasons.

\begin{tabular}{|c|c|c|c|c|c|c|c|c|}
\hline \multirow{3}{*}{ Planting system } & \multicolumn{8}{|c|}{ Mean number of insect /sample } \\
\hline & \multicolumn{2}{|c|}{ Aphis gossypii } & \multicolumn{2}{|c|}{ Spodoptera littoralis } & \multicolumn{2}{|c|}{ Thrips tabaci } & \multicolumn{2}{|c|}{ Coccinella spp. } \\
\hline & 2011 & 2012 & 2011 & 2012 & 2011 & 2012 & 2011 & 2012 \\
\hline Solid & 17.42 & 13.60 & 16.52 & 13.73 & 12.53 & 9.79 & 4.70 & 4.59 \\
\hline Intercropping & 12.7 & 11.96 & 18.00 & 13.02 & 9.71 & 7.70 & 2.42 & 2.63 \\
\hline F. test & NS & NS & NS & NS & NS & NS & NS & NS \\
\hline L.S.D. $0.05 \%$ & 6.80 & 12.92 & 5.78 & 4.53 & 6.80 & 6.80 & 4.53 & 3.58 \\
\hline
\end{tabular}

Means in same column showing different letters differ significantly $\mathbf{P}<0.05$

\section{c-Thrips tabaci:}

Results in Table (2) clear that intercropping Maize with Soybean affected T. tabaci infestation on solid Soybean during 2011 and 2012 seasons, respectively. While intercropping system showed considerable decrease of infested Soybean plants during the two seasons of study, respectively. The mean numbers recorded 12.53 and 9.79 insects in 2011 and 2012; 9.71 and 7.70 in the two investigated seasons of study for solid and intercropping systems, respectively.

\section{1-2-Insects predators (Coccinella spp.):}

Results tabulated in Table (2) indicate that Soybean plants harbored higher numbers of Coccinella spp. in solid plantation than in intercropping system seasons during 2011 and 2012 seasons. That means that, intercropping system showed considerable decrease in Coccinella spp. on Soybean plants during the two seasons of study, respectively. Where the mean numbers were $(4.70 \&$ 4.59) in 2011 season, but in season 2012 were (2.42 \& 2.63) for solid and intercropping systems, respectively.

These results agree with Shabeen, (1977); Mohammed (1981); Bachatty (1984) and Mohamed et al. (1992) who recorded that intercropping Soybean with Maize suffered fewer population density of insect pests than on Soybean growing in solid.

\section{II-Effect of sowing date on: \\ II-1-Insect pests attacking Maize plants: a-Aphids:}

Statistical analysis of the obtained results presented in Table (3) showed that the differences between the insect numbers recorded on Maize plants in the different sowing dates were significant. The lowest mean number of aphids recording 112.97 insects/10 plants in season 2011and $101.278 / 10$ plants in season 2012. While the estimated counts with the first planting date $\left(3^{\text {rd }}\right.$ week of May) showed relatively high numbers of aphis recording 1026.89 in season 2011and 676.34/sample which was recorded in season 2012 was estimated with the third planting date (1 week of July).

\section{b- Sesamia cretica:}

Data presented in Table (3) show that Maize plants sown on the $3^{\text {rd }}$ week of May harbored the highest number of $\boldsymbol{S}$. cretica recording 10.13 and 9.61insects/sample during two seasons, respectively. It is worth to mention that third sowing date showed, relatively, low numbers of $\boldsymbol{S}$. cretica recording 3.56 and 2.47 insects/sample in the two investigated seasons, respectively.

Table 3. Effect of planting date on the population density of some insect pests and coccinellid predators on Maize plants at Minia El-Kamh, Sharkia Governorate during 2011 and 2012 seasons.

\begin{tabular}{|c|c|c|c|c|c|c|c|c|c|c|}
\hline \multirow{3}{*}{ Sowing dates } & \multicolumn{10}{|c|}{ Mean number of insects / 10 Maize plants } \\
\hline & \multicolumn{2}{|c|}{$\begin{array}{c}\text { Aphis } \\
\text { gossypii }\end{array}$} & \multicolumn{2}{|c|}{ Sesamia critica } & \multicolumn{2}{|c|}{ Ostrinia nubilalis } & \multicolumn{2}{|c|}{$\begin{array}{c}\text { Chilo } \\
\text { agamemnon }\end{array}$} & \multicolumn{2}{|c|}{ Coccinella spp. } \\
\hline & 2011 & 2012 & 2011 & 2012 & 2011 & 2012 & 2011 & 2012 & 2011 & 2012 \\
\hline $3^{\text {rd }}$ week of May & 112.97c & $101.278 \mathrm{c}$ & 10.13 & $9.61 \mathrm{a}$ & $6.63 \mathrm{c}$ & 7.25 & 6.22 & 5.18 & 10.48 & 9.08 \\
\hline $2^{\text {nd }}$ week of June & $442.22 \mathrm{~b}$ & 393.200b & 5.49 & $4.82 \mathrm{~b}$ & 10.27ab & 11.21 & 8.32 & 8.79 & 9.33 & 7.94 \\
\hline $1^{\text {st }}$ week of July & 1026.89a & $676.34 \mathrm{a}$ & 3.56 & $2.47 \mathrm{~b}$ & $11.14 \mathrm{a}$ & 12.61 & 8.91 & 8.71 & 10.76 & 9.58 \\
\hline F. test & $* *$ & $* *$ & NS & $*$ & $*$ & NS & NS & NS & NS & NS \\
\hline L.S.D. ${ }_{0.05 \%}$ & 115.97 & 115.65 & 7.11 & 3.46 & 3.99 & 6.21 & 3.99 & 5.41 & 7.11 & 3.99 \\
\hline
\end{tabular}

Means in same column showing different letters differ significantly $\mathrm{P}<0.05$ 


\section{c- Ostrinia nubilalis:}

Statistical analysis of the obtained results Table 3 revealed that the differences between the insect numbers in the different sowing dates were nonsignificant during the first and second seasons. Maize plants sown on the $3^{\text {rd }}$ week of May were attacked with the lowest numbers of $\boldsymbol{O}$. nubilalis recording (6.63 \& 7.25) insects/sample during 2011 and 2012 seasons, respectively. While in the third sowing date $\left(1^{\text {st }}\right.$ week of July) showed relatively high number of O. nubilalis on plants recording 11.14 and 12.61 insects/sample during the first and second seasons, respectively.

\section{d-Chilo agamemnon:}

Also, statistical analysis of the obtained results (Table, 3) pointed out that the differences between the insect numbers recorded in the different sowing dates were non-significant during the first and second seasons of investigation. Maize plants sown on the $3^{\text {rd }}$ week of May harbored the lowest numbers of $\boldsymbol{C}$. agamemnon recording 6.22 and 5.18 insects/sample during seasons 2011 and 2012, respectively. While, the relatively high numbers of $\boldsymbol{C}$. agamemnon on Maize plants recorded 8.91 and 8.71 insects/sample in case of the third sowing date ( $1^{\text {st }}$ week of July) during the first and second seasons, respectively.

Generally, results given in Table (3) showed that delaying the sowing date from $3^{\text {rd }}$ week of May to $1^{\text {st }}$ week of July resulted a significant increase in population density of different insect pests under study, except in case of $\boldsymbol{S}$. cretica as it took reverse trend.

\section{II- 2-Insect predators (Coccinella spp.):}

Results presented in Table 3 indicate that the lowest numbers of the predators, Coccinella spp. 9.33 and 7.94 insects/sample were recorded on Maize plants sown on the $2^{\text {nd }}$ week of June in the two seasons of study, respectively. While, with the third sowing date $1^{\text {st }}$ week of July the relatively high numbers of Coccinella spp. 10.76 and 9.57 insects/sample were estimated on Maize plants during the first and second seasons, respectively. The obtained results are in accordance with those obtained by El-Hariry (1979); Helaly et al. (1982); Abd-El-Rahim et al. (1991); Abd-El Salam and Shahinaz (1993) and Semeada et al. (1993).

\section{II-2-Soybean plants:}

1-Insect pests attacking Soybean plants: a-Aphis gossypii:

The presented data in Table 4 show that the differences between the numbers of aphids on Soybean plants cultivated in the three sowing dates were significant during 2012 season. Soybean plants sown on the $3^{\text {rd }}$ week of May were attacked with lowest numbers of $\boldsymbol{A}$. gossypii 8.60 insects/sample in season 2012. While, in 2011 season the differences between numbers of aphids were nonsignificant.

\section{b-Spodoptera littoralis:}

Also, results in Table (4) reveal that the lowest number of $\boldsymbol{S}$. littoralis (11.18) was recorded in the first sowing date of 2012 season. While, the highest number (18.93) was recorded at the same sowing date but in 2011 season. Results showed that the population of insects increased again by delaying sowing date to 1 ast week of July during the second season, 2012.

Table 4. Effect of planting date on the population density of some insect pests and coccinellid predators on Soybean plants at Minia El-Kamh, Sharkia Governorate during 2011 and 2012 seasons.

\begin{tabular}{lllllllll}
\hline \multirow{2}{*}{ Sowing dates } & \multicolumn{1}{c}{ 10 leaves /sample } \\
\cline { 2 - 10 } & \multicolumn{2}{c}{ Aphis gossypii } & \multicolumn{1}{c}{ Spodoptera littoralis } & Thrips tabaci & \multicolumn{2}{c}{ Coccinella spp. } \\
\cline { 2 - 10 } & 2011 & 2012 & 2011 & 2012 & 2011 & 2012 & 2011 & 2012 \\
\hline $3^{\text {rd }}$ week of May & 15.13 & $8.60 \mathrm{~b}$ & 18.93 & 11.18 & 10.47 & $8.76 \mathrm{ab}$ & $3.37 \mathrm{~b}$ & 3.52 \\
$2^{\text {nd }}$ week of June & 13.70 & $13.93 \mathrm{ab}$ & 14.48 & 12.67 & 10.23 & $8.16 \mathrm{~b}$ & $4.01 \mathrm{a}$ & 3.81 \\
$1^{\text {st }}$ week of July & 15.61 & $16.07 \mathrm{a}$ & 18.37 & 16.26 & 11.73 & $9.32 \mathrm{a}$ & $3.29 \mathrm{~b}$ & 3.51 \\
F. test & $\mathrm{NS}$ & $* *$ & $\mathrm{NS}$ & $\mathrm{NS}$ & $\mathrm{NS}$ & $* *$ & $*$ & $\mathrm{NS}$ \\
L.S.D. 0.05 & 5.41 & 5.65 & 4.76 & 6.92 & 4.76 & 4.76 & 3.46 & 2.82 \\
\hline
\end{tabular}

Means in same column showing different letters differ significantly $\mathbf{P}<0.05$

\section{c-Thrips tabaci:}

Data presented in Table (4) show that T. tabaci infested Soybean plants which were sown in three tested dates during the two seasons of investigation 2011 and 2012, respectively. At the third sowing date $\left(1^{\text {st }}\right.$ week of July Soybean plants harbored relatively high numbers of $\mathbf{T}$. tabaci recording 11.73 and 9.32 insects/sample during the first and second season, respectively.

\section{II-2-Insect Predators (Coccinella spp.):}

Data shown in Table (4) show the coccinellid predators occurrence on Soybean plants sown in the three tested dates during seasons 2011 and 2012. Statistical analysis of the obtained results revealed that the differences between Coccinella spp. 
numbers recorded in the different sowing dates were nonsignificant.

The obtained results are in agreement with Shabeen (1977); Attia et al. (1987) and Abd-ElSalam and Shahinaz (1993), who mentioned that the sowing date has an effective role on the level of insect population density infesting Soybean and the Leguminous plants.

\section{References}

Abd-El-Rahim, M. M.; M. I. Abdel-Fattah; A. I. Farag and M. A. Z .El-Naggar. (1991): Contribution to the study of corn leaf aphid, Rhopalosiphum maidis Fitch. On Maize plants.Bull.Entomol.Soc. Egypt. 70:91.98.

Abd-El-Salam, A. Shahinaz (1993): Ecological studies on aphid species attacking Maize plants. M.Sc. Thesis, Fac. Agric. Cairo Univ.222 pp

Attia, M. B.; A. I. Farag and M. Abd-Eahim (1987): Survey and seasonal abundance of corn borers at Menoufia province indicated by light trap. (ISMA) Hungary, 24-29 August.

Atungwu, J. J. and S. O. Afolami (2001): Field assessment of resistance of some Glycine max (L.) Merrill) lines and varieties to Meloidogyne spp. using a combination of gall-index and grain yield. Trop. Oil Seeds J. (6): 41-49.

Ayeni, A. O. (1987): Maize production in Nigeria: Problems and prospects. J. Fd. Agric. (2): 123129.

Bachatty, M. A. (1984): Ecological and biological studies o Soybean pests. M.Sc. Thesis Fac. Agric. Zagazig Univ.

Egbe, O. M. (1995): Effects of plant densities of intercropped local sorghum (Sorghum bicolour L. Moench) with soybean (Glycine max L. Merrill) varieties on yield and productivity of soybean/sorghum intercropping in southern
Guinea Savanna. M. Sc.Thesis, Univ. Agric. Bauchi., Nigeria, Makurdi.

El-Hariry, M. A. (1979): Biological studies on aphids attacking corn and wheat in Egypt .M. Sc. Fac. Agric. Ain Shams Univ.187 pp

Fisher, A. R. (1950): Statistical method for research worker. Oliver and Poyed Edinburgh and London 312 pp.

Helaly, M. M.; A. E. Ibrahim and M. R. A. Saleh (1982): Fluctuation of population in densities of Empoasca sp., Aphis craccivora KOk. on Cowpea plants at Zagazig, Egypt. Bull. Soc. Egypt. No.64:35-43.

Mohammed, K. K. (1981): Ecological studies on certain pests attacking Soybean. Ph.D. Thesis. Fac. Agric. Assiut. Univ.Egypt.187pp.

Mohamed, Z. A. ; Shadia-Omara M. and S. M. A. EL-Shakaa (1992): Effect of Maize and Cowpea intercropping plants on the occurrence of some insect pests attacking both Cowpea and Maize plants at Zagazig region ,Sharkia Governorate, Egypt. Menofia. J. Agric. Res. 17 (4): 2047-2069.

Muoneke, C. O. and J. E. Asiegbu, (1997): Effects of okra planting density and spatial arrangement in intercrop with Maize on the growth and yield of the component species. J. Agron. Crop Sci. 179: 201-207.

Semeada, A. H.; I. I. Ismail and A. A. A. Sharaf El-Din (1993): Effect of plant density of Maize on the infestation with some insect pests and resulting yield loss. Bull. Fac. Agric. Univ. Cairo: 477-487.

Shabeen, A. H. (1977): Survey of pests attacking Soybean plants in Egypt with some ecological notes .Agric. Res. Rev., 55 (10):59-65.

Youssef-Ez-El-din (1990): Ecological and biological studies on Maize aphid insect. M. Sc. Thesis Fac. Agric. Ain Shams Univ. 
تاثير نظم التحميل وتواريخ زراعة الذرة على تعداد بعض الاقات الحشرية ومفترسات خنافس أبو العيد المصاحبة لها

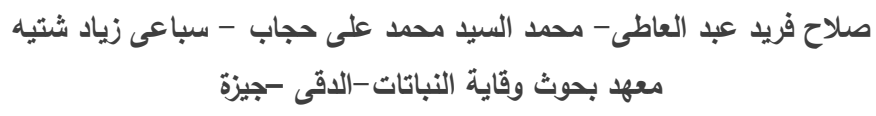

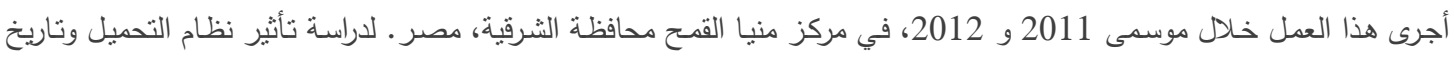

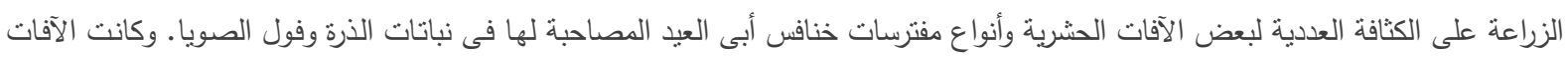

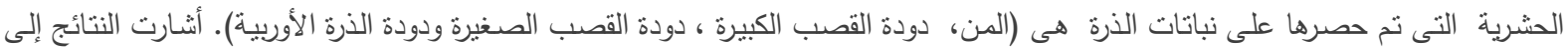

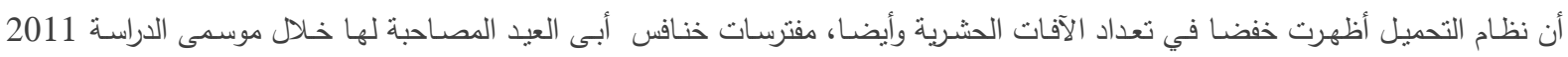

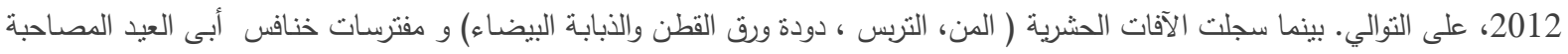

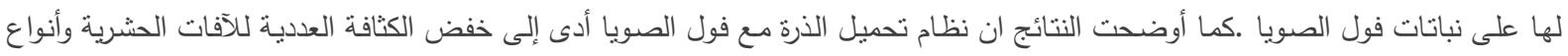

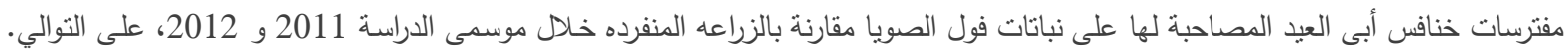

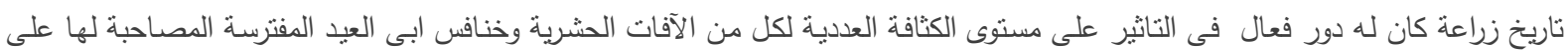

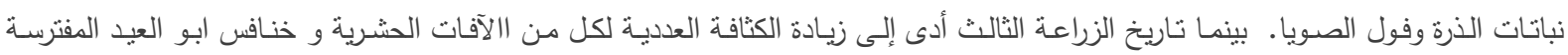

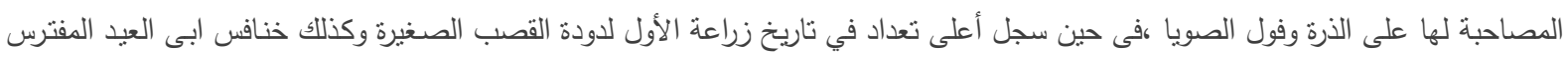
على نباتات فول الصويا خلال موسمى الدراسة 2011 و 2012، على النوالي. 